\title{
Çarkıfelek (Passiflora spp L.) türlerinde çoğaltma teknolojisindeki gelişmeler
}

\author{
Advances in propagation technology in Passionflower (Passiflora spp L.) species
}

\author{
Kazım MAVi' ${ }^{\wedge}$ (iD, Fulya UZUNOĞLU1 ${ }^{1 i}$ \\ ${ }^{1}$ Hatay Mustafa Kemal University, Faculty of Agriculture, Department of Horticulture, Antakya-Hatay, Turkey.
}

MAKALE BILGISI / ARTICLE INFO

Makale tarihçesi / Article history:

DOI: $\underline{10.37908 / m k u t b d .639798}$

Geliş tarihi /Received:30.10.2019

Kabul tarihi/Accepted:17.02.2020

\section{Keywords:}

Ornamental plant, aromatic plant, alternative fruit.

\footnotetext{
Corresponding author: Kazım MAV

$\bowtie:$ kazimmavi@mku.edu.tr
}

\author{
ÖZET / ABSTRACT
}

\section{Atıf / Citation: Mavi K, Uzunoğlu F (2020) Çarkıfelek (Passiflora spp L.) türlerinde çoğaltma teknolojisindeki gelişmeler. MKU. Tar. Bil. Derg. 25(1) : 84-100. DOI: 10.37908/mkutbd.639798}

\section{GiRiş}

Çarkıfelek Passiflora cinsi içerisindeki birçok türe verilen genel bir isimdir. Dünyada çarkıfelek bitkisinin taze ve endüstriyel tüketime imkan veren, çok farklı şekillerde süs bitkisi olarak kullanılan ve bitkisinin farklı kısımları tıbbi özellikleri (Uzunoğlu ve Mavi 2014) için kullanılan 500'den fazla türü olduğu tahmin edilmektedir (Grisi ve ark. 2019). Bu türlerin çoğu, Amerika Birleşik Devletlerinden Arjantin'e kadar, Asya kıtasında ise Avusturalya ve Çin'de doğal olarak bulunmakla birlikte, Brezilya, Kolombiya, Ekvator, Bolivya ve Paraguay'ı içerisine alan Tropikal Güney Amerika orjinlidir. Brezilya'da 89 çarkıfelek türü endemik olarak bulunduğu için, Brezilya biyoçeşitliliğinin anavatanı olarak kabul edilmektedir (Cerqueira-Silva ve ark. 2014).

Çarkıfelek türlerinden birçoğu Güney Amerika ülkelerinde ticari olarak kapama bahçe şeklinde yetiştirilmektedir (Şekil 1). Brezilya ve Kolombiya çarkıfelek türlerini meyvesi için yetiştiren en geleneksel ülkelerdir (Ospina-Torresve ark. 2018). Ülkemizde ise
Antalya Gazipaşa'da üretim yapan bazı işletmeler bulunmaktadır. Passiflora edulis Sims (ekşi çarkıfelek, sarı çarkıfelek, Maracuya) türü Brezilya çarkıfelek yetiştiriciliğinde meyve bahçelerinin \%90'ından fazlasını kaplamaktadır (Bernacci ve ark. 2008). P. alata Curtis (tatlıçarkıfelek), $P$. setacea DC. ve $P$. cincinnata Mast. Brezilya'da ticari olarak yetiştiriciliği yapılan diğer türlerdir. Bu türlerin yanı sıra $P$. edulis Sims f. edulis, $P$. nitida Kunth, $P$. quadrangularis L. ve $P$. maliformis $L$. yerel olarak yetiştirilen türlerdir. Brezilya'da son yıllarda bazı Avrupa ülkelerinde süs bitkisi olarak kullanılan çarkıfelek melezlerinin de yetiştiriciliğine başlanmıştır (Abreu ve ark. 2009). Antakya koşullarında ise P. edulis ve $P$. caerulea hobi amaçlı olarak meyveleri ve süs özellikleri için yetiştirilen türlerdir (Şekil 1 ve 2).

Kolombiya'da, ise altı farklı çarkıfelek türü ticari olarak yetiştirilmektedir. Bunlardan en yaygın olanı $P$. ligularis Juss (Granadilla) türüdür. P. edulis Sims, $P$. edulis Sims $f$. edulis, P. maliformis L., P. tripartita Poir. var. mollissima (Kunth) Holm-Niels. \& P. Jørg. ve P. quadrangularis L. 
diğer yetiştiriciliği yapılan türlerdir (Miranda ve ark. 2009).
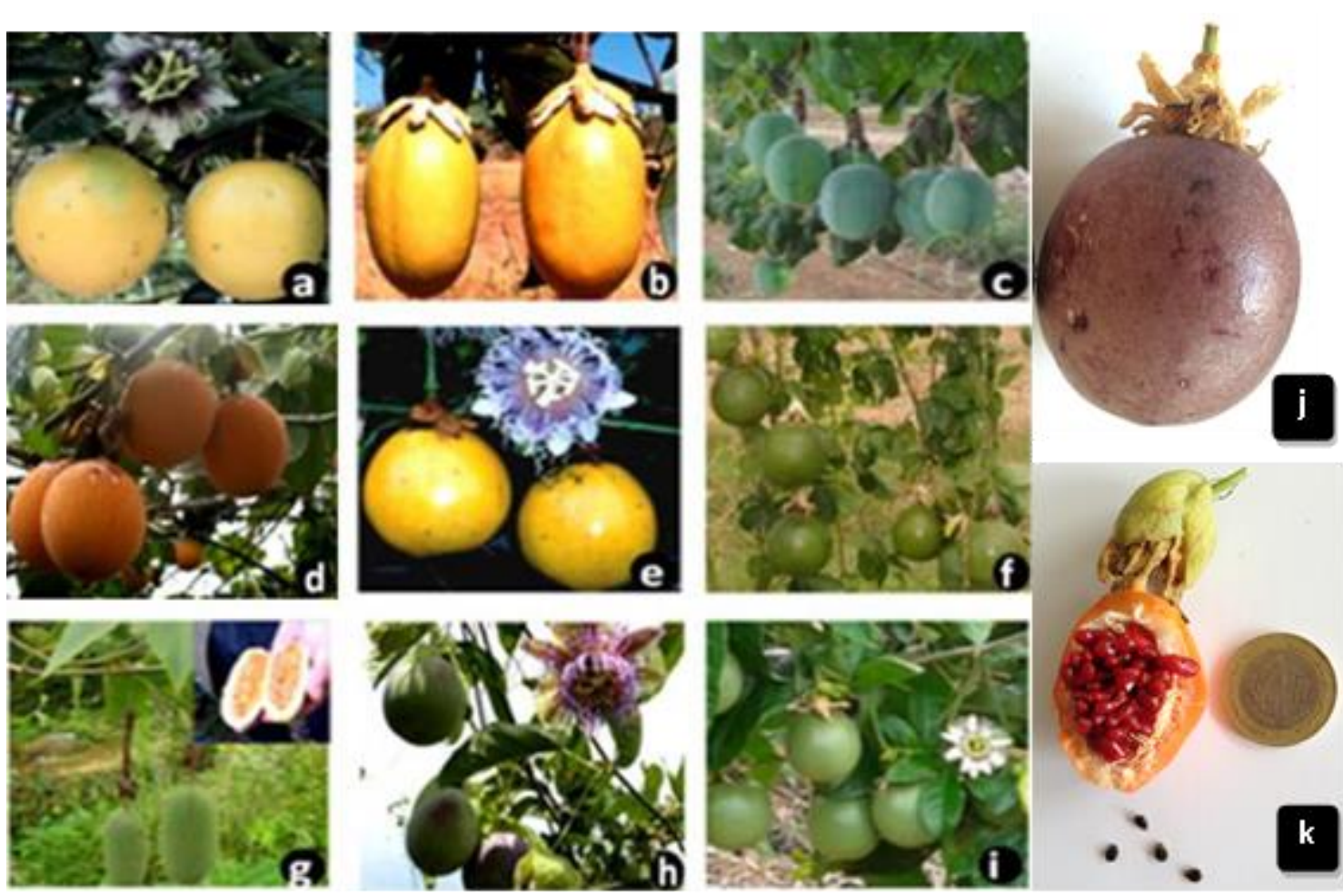

Şekil 1. Ticari çarkıfelek türleri: P. edulis Sims (a); P. alata Curtis (b); P. setacea DC. (c); P. ligularis Juss. (d); P. nitida Kunth (e); P. cincinnata Mast. (f); P. tripartita (Juss.) Poir. (g); P. maliformisL. (h); P. edulis Sims f. edulis (i) (CerqueiraSilva ve ark. 2018). Antakya koşullarında hobi amaçlı üretilen türler: $P$. edulis Sims f. edulis (j) ve $P$. caerulea $(\mathrm{k})$

Çoğu ticari çarkıfelek türü kendine uyuşmazlık göstermektedir. Bu nedenle, çiçeklenme döneminde döllenme ve meyve tutumu için farklı bitkiler arasında tozlanmaya intiyaç duymaktadır. Çarkıfelek üretimi yapılacak kapama bahçelerde genetik olarak farklı bitkilere ihtiyaç duyulması meyve üretimini kısıtlayan en önemli faktördür (Bruckner ve ark. 1995). Generatif (tohumla) çoğaltma, diğer meyve türlerinden farklı olarak çarkıfelek türlerinin çoğunda meyve üretimi için kullanılmaktadır (Meletti 2011). Ancak bazı durumlarda çelik, aşı ve doku kültürü yöntemleri ile klonal çoğaltma da yapılmaktadır (Leonel ve Pedroso, 2005).

Çarkıfelek türlerinden bazılarında generatif çoğaltma sırasında tohum çimlenme problemlerine rastlanmaktadır. Dormansi (Oliveira ve ark. 2010), rekalsitrant tohum tipine sahip olma (Faleiro ve ark. 2019) gibi tohumların genetik ve fizyolojik kalitesi ile ilgili hususlar, üretim sisteminde kullanılacak aşı kalitesini doğrudan etkilemektedir. Vejetatif çoğaltma açısından ise en önemli faktörler ebeveyn bitkilerin genetik ve fizyolojik kalitesi, farklı çoğaltma yöntemleri, çoğaltma ortamları, köklenmenin artırılması için kullanılan bitki büyümeyi düzenleyicilerin kullanımı ve aşı başarısıdır. Çarkıfelek türlerinin çoğaltılması özellikle Brezilya ve Kolombiya'da birçok araştırııının araştırmalarına konu olmuştur (Ferrreira 2000, Vaz ve ark. 2009, Pires ve ark. 2011, Alexandre ve ark. 2013a, Alexandre ve ark. 2016). Bu derleme ile ülkemiz için yeni bir bitki türü olarak kullanılabilecek çarkıfelek türlerinin daha önce yapılan çalışmalar üzerinden farklı çoğaltma yöntemleri ve uygulamalarının bilimsel ve teknolojik gelişmeler de ilave ederek açıklanması hedeflenmiştir. Ayrıca çarkıfelek türlerinin taze tüketim, gıda hammaddesi, tıbbi bitki ve süs bitkisi olarak farklı kullanım alanları göz önünde bulundurularak ülkemizde yapılacak yeni çalışmalara temel oluşturulacaktır. 

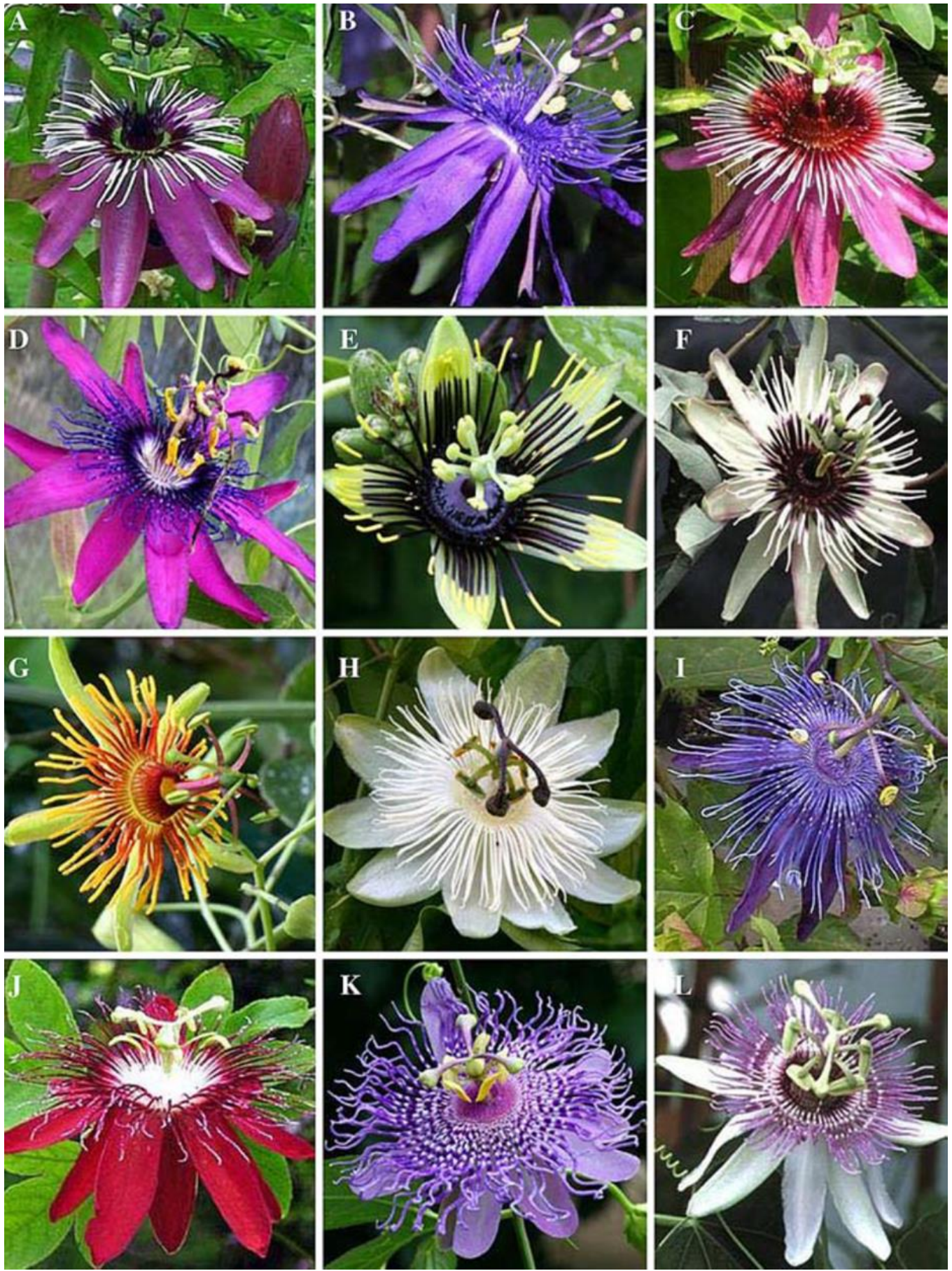

Şekil 2. Süs bitkisi olarak kullanılan bazı melezler: A P. xviolacea T. Milne; B P. 'Cary' H. Gommer; C P. 'Anastasia' J. Brander; D P. 'Etna' M. Vecchia; E P. 'Manta' M. Vecchia; F P. 'Stella di Cremona' M. Vecchia; G P. 'Sunburst' P. Worley; H P. 'White Queen' R. Fisher \& H. Wouters; I P. 'Jelly Joker' C. Laurens; J P. 'Lady Margaret' C. Feuillet; K P.'Fata Confetto' M. Vecchia; L P. 'Serena' M. Vecchia (Abreu ve ark. 2009)

\section{Generatif Tohumla Çoğaltma}

\section{Genel prensipler ve uygulamalar}

Tohumla çoğaltma, ticari olarak yetiştirilen çok sayıda çarkıfelek türü, özellikle de gıda olarak kullanılanlar için düşük maliyetli ve kolay bir yöntem olduğundan en yaygın olarak kullanılan çoğaltma yöntemidir (Coelho de Araújove ark. 2007). Bu yöntemin avantajları arasında fidan üretiminin basit olması, daha kısa sürede fidan üretimi, meyve bahçesinde daha az emek ve altyapı talebi istemesi, tohumların ticareti ve nakliyesinin daha kolay olması ve yetiştiriciler için ciddi sorunlara neden olan virüslerin tohumlar tarafından aktarılmadığı için virüsten arındırımış fidan üretimi sağlaması olarak sayılabilir. Tohumdan çıkan bitkilerin çarkıfelek türlerinde kullanılmasının diğer bir avantajı ise, bahçede 
genetik olarak farklı bitkiler bulunması nedeniyle tozlanma, döllenme ve meyve tutumu sırasında sorunlar oluşmayacaktır. Klonal çoğaltılan çarkıfelek türlerinde oldukça karmaşık kendine uyuşmazlık mekanizmasından dolayı tozlanma, döllenme ve meyve tutumu gerçekleşmemektedir. Tohumdan çıkan bireylerde ise genetik farklılık nedeniyle mutlaka diğerlerini tozlayıp dölleyecek bitkilerin meydana geldiği görülmektedir. Tohumlardan üretilen bitkilerin en önemli dezavantajı ise, meyvelerin ticari değerinin düşmesine neden olan ve farklı ürün işleme uygulamalarını zorlaştıran düzensiz bir bahçeye neden olabilecek yüksek bir genetik çeşitlilik göstermeleridir.

Genetik gelişimde tohumla çoğaltmanın, tür içi veya türler arası melezleme ve seçim aşamaları sonrasında sadece bir tohumda istenilen farklı karakteristik özelliklerin bir araya getirilmesine imkan sağlayabileceği göz önüne alındığında vazgeçilmez bir yöntem olduğu söylenebilir (Cerqueira-Silva ve ark. 2014).Tohumla çoğaltmanın bir diğer önemli yanı ise genetik kaynakların korunması amacıyla kullanıldığında ortodoks tohumlara sahip çarkıfelek türlerinin çimlenme kapasitelerini düşük sıcaklıklarda ve düşük nemde saklandığında muhafaza etmenin daha kolay olmasıdır.

\section{Çimlenme ve tohum depolama}

Farklı çarkıfelek türlerinden en yüksek ekonomik önemi sahip olan Passiflora edulis Sims türü, tohum çimlenmesi ve depolanması konularında üzerinde en fazla çalışılan türdür. Ancak çok geniş bir çeşitliliğe (500'den fazla tür) sahip olan pasiflora türlerinden birçoğu için tohum çimlenme ve depolama konusunda yeterli bilgilerin olmadığı söylenebilir. Türler arasındaki farklııkların yanı sıra, aynı türdeki farklı genotipler (Alexandre ve ark. 2004) ve çeşitler arasında da farklılıklar olduğu bildirilmektedir. Bunun yanı sıra tohum kalitesi ve fizyolojik olgunluğu (Aguacía ve ark. 2015), dormansi bulundurup bulundurmaması (La Rosa 1984, Delanoy ve ark. 2006, Oliveira ve ark. 2010, Rego ve ark. 2014, Marostega ve ark. 2017, Torres 2018), tohum ekstraksiyonu, işlemesi ve depolaması sırasındaki işlemlerde (Pereira ve Dias 2000, Aguacía ve ark. 2015) dahil olmak üzere diğer birçok faktörün çarkıfelek türlerinde tohum çimlenmesi ve depolanmasını etkilediği bildirilmektedir.

Farklı çarkıfelek türlerinde tohumlarla ilgili yapılan çalışmalar çimlenmenin düşük ve düzensiz olduğunu, yani çimlenmenin başlangıcı ile bitişi arasında türlerin yetiştirilmesi sırasında sorun yaratan düzensiz fide oluşumu ile sonuçlanan uzun bir süre olduğunu bildirmişlerdir (Kuhne1968, Pereira ve Dias 2000). Diğer bir netliğe kavuşturulamamış konu, birçok çarkıfelek türü tohumlarının rekalsitrant olması ve oda sıcaklığında canlılığını hızla kaybetmesidir (Faleiro ve ark. 2019). Bu tip tohumlar bilindiği gibi kurutmaya toleransları bulunmaz. Bu nedenle uygun olmayan depolama ve düşük nemde saklama koşullarında, tohum canlııklarını hızıı bir şekilde kaybetmektedirler.

Düşük ve düzensiz çimlenmenin sebeplerinden biri, tohumların farklı fizyolojik olgunlukları ve kaliteleridir. Pek çok çarkıfelek türü, tohumların farklı fizyolojik olgunluklarına yol açabilecek düzensiz bir meyve olgunluk aşaması üreten sürekli çiçeklenme göstermektedirler (Nave ve ark. 2010). Bu nedenle, kaliteli tohum eldesi için tohumluk meyvelerin hasat zamanı çok önemlidir. Ayrıca, bu hasat zamanı çarkıfelek türlerine ( $P$. edulis, Negreiros ve ark. 2006, $P$. edulis $f$. flavicarpa, Battistus ve ark. 2014, P. ligularis, Aguacía ve ark. 2015, P. mollissima Salazar ve Ramirez 2017) ve yetiştirildikleri iklim koşullarına göre değişiklik gösterebilmektedir. Negreiros ve ark. (2006) meyve gelişiminin tohum kalitesi üzerine etkisini belirleyebilmek için yaptıkları çalışmada $P$. edulis Sims türü için ikinci (\% 5 ile \% 50 sarı renkli meyveler) ve üçüncü (sarı \% 50'nin üzerinde meyveler) olgunlaşma evresindeki meyvelerden tohum ekstraksiyonu yapılması gerektiğini belirlemişlerdir. Hasat sonrasında yapılan işlemler de tohumun fizyolojik olgunluğuna, kalitesine ve depolama süresine etki etmektedir. Tohumluk meyve olgunluğunun yanı sıra fermantasyon yönteminin de tohum kalitesi üzerine etkisinin olduğu bildirilmektedir (Aguacía ve ark. 2015). Negreiros ve ark. (2006), P. edulis meyvelerinden 3-6 günlük depolamadan sonra ekstrakte edilmiş tohumların daha iyi bir fizyolojik kalite gösterdiğini bildirmişlerdir. Fermantasyonun bu olumlu etkisi, tohum kabuğu içerisindeki çimlenmeyi engelleyici organik madde ve inorganik tuzları azaltmasından kaynaklanmaktadır.

Çarkıfelek türlerinde tohum depolama ve çimlenme ile direkt ilişkili önemli bir diğer konuda dormansidir (Alexandre ve ark. 2004, Passos ve ark. 2004, Delanoy ve ark. 2006, Padua ve ark. 2011). Dormansi tohum çimlenmesi için tüm koşullar optimum olsa bile canlı tohumların çimlenmesini engelleyen fizyolojik bir mekanizmadır. Bu mekanizma bazı türler için tohum çimlenmesini geciktirerek veya uygun zaman dışında çimlenmesini engelleyerek türün hayatta kalma şansını arttırmaktadır. Yabani veya kültür formu olmayan türlerde dormansi daha genel bir mekanizma iken, kültür çeşitleri hızlı ve birörnek çimlenme performansı göstermektedirler.

Dormansi, endogenik (embriyo ile ilişkili) ve ekzogenik (endosperm, integüment ve meyve kaynaklı diğer bariyerlerden) olarak sınıflandırılabilir. Ayrıca primer 
veya doğal ve sekonder veya teşvik edilmiş dormansi olarak da sınıflandırımaktadır (Vivian ve ark. 2008). Dormansi tiplerine bağlı olarak, embriyonun rudimenteri veya olgunlaşmamış olması, tohum kabuğunun geçirimsiz olması veya bu sebeplerin birlikte görülmesi gibi değişik nedenleri olabilmektedir. Tohumlarda dormansinin kırılmasında bitki büyümeyi düzenleyiciler, kimyasal ve mekanik aşındırma, in vitro embriyo çimlendirme, sıcak su ve farklı koşularda nemlendirme uygulamaları kullanılabilmektedir. Farklı çalışmalarda (Miranda ve ark. 2013) bazı çarkıfelek türlerinde tohumla çoğaltmanın avantajları olduğu bildirilerek, tohumlarındaki dormansinin kırılması (Marostega ve ark. 2017) ve tohum depolama yöntemlerinin (Grzybowski ve ark. 2019) yanı sıra tohum histolojileri, fizyolojileri ve biyokimyasal aktiviteleri (Tozzi ve Takaki 2011) çalışılmıştır. Bu çalışmalardan yola çıkarak tüm çarkıfelek türleri için dormansi tipini ve dormansiyi kırıcı uygulamaları genellemek mümkün değildir. Bu yüzden türler arasında ve tür içindeki genotiplerin ve çeşitlerin dormansi konusundaki genetik farklılıklarının çalışııması gerekmektedir.

Tür içi ve türler arası bu çeşitliliğin, çimlenme oranlarında, tohumlarda dormansi bulunup bulunmadığında, dormansi kırma uygulamalarındaki farklılıklarda, depolama sırasında ve sonrasındaki tohum canlılığı ve gücünde bazı zıtlıklar oluşturduğu kaynaklarda bildirilmiştir. Örneğin Morley-Bunker (1980) çarkıfelek türlerinin bazılarının tohumları geçirimsiz tohum kabuğu nedeniyle dormansi bulunduğunu ve bunların giderilmesinde bazı uygulamaların yapılması gerektiğini ifade etmiştir. Ellis ve ark. (1985) ise çarkıfelek tohumlarının su aldığını ancak tohumlarının çimlenmeyi engelleyici bazı maddeler içerdiklerini rapor etmişlerdir. Wagner Junior ve ark. (2005) çarkıfelek türlerinin bazılarında tohumların su almadığını, su alanlarda ise su alım sürelerinin aynı olmadığını belirlemişledir.

Tohum depolanabilirliği, tohum gen bankalarındaki genetik kaynakların korunmasında üretilen tohumların taşınma planlanmasında ve çeşitlere ait tohumların ticarileşmesinde çok büyük öneme sahiptir. Türler arasındaki tohum kurutmaya toleranstaki farklılıklarının analizi, oransal nem, sıcaklık, çimlenme öncesi uygulamalar ve depolama stratejilerini daha iyi tanımlamak ve tohumdan üretilecek ticari fidan eldesi için temeldir. Doğaldır ki bu yanıtlar türden türe farklılık gösterebilecektir. Hatta tür içerisindeki çeşit ve genotipler arasında da varyasyon gösterebilir. Padua ve ark. (2011) Passiflora setacea DC. tohumlarının tohum nem seviyelerinin \%4'e kadar düşürülebileceğini, yani kurutmaya tolerans gösterdiğini bildirmişlerdir.
Tohumların $0^{\circ} \mathrm{C}^{\prime}$ nin altında depolanmasının bu türde tohum ömrünü uzattığını saptamışlardır. Özellikle karyoprezervasyon (çok düşük tohum neminde, çok düşük sıcaklıkta uzun süreli depolama) tohum depolamasında Ospina ve ark. (1998) tohum nem içeriğinin kritik faktör olduğunu aktarmışlardır. Bazı çarkıfelek türlerinin ise tohumlarının kurutmaya tolerans açısından intermediate olduğu nispeten düşük sıcaklıklarda depolanabilmelerine rağmen, $0^{\circ} \mathrm{C}^{\prime}$ nin altındaki sıcaklıklarda zararlandıkları bildirilmektedir (Ellis ve ark. 1985). Ayrıca kurutmaya tolerans göstermeyen (rekalsitrant) bazı çarkıfelek türlerinin de bulunduğu bildirilmektedir. Bu türlerin tohumları tohum nemlerinin düşürülmesine ve düşük sıcaklıklarda depolanmaya uygun değillerdir (Meletti ve ark. 2007, Veiga-Barbosa ve ark. 2013). Kesinlikle farklı tür ve genotiplerin tohumlarında daha net bilgiler elde edebilmek için çalışmalara devam edilmesine gereksinim duyulmaktadır.

\section{Çarkıfelekte tohumdan fidan üretimi}

Güçlü ve birörnek fideler elde edebilmek için tohumun fizyolojik, genetik ve sağlık kalitesi bitki çoğaltmasındaki başarının anahtarıdır. Bazı türlerde, depolama işlemleri sırasında dormansinin teşviki veya doğal dormansi nedeniyle düşük çimlenme oranları görülebilir. Passiflora setacea DC. cv. BRS Pérola do Cerrado (BRS PC) ve Passiflora cincinnata Mast. cv. BRS Sertão Forte (BRS SF) çeşitlerinde dormansinin kırılması için tohumlarının $\mathrm{GA}_{4}+7+\mathrm{N}$-(fenilmetil)-aminopurin (Zucarelli ve ark. 2009, Costa ve ark. 2015) ile uygulamasından başarılı sonuçlar alınmıştır. Bu çeşitlerde fidelerin ticari olarak üretilebilmesine olanak sağlamıştır.

Fidan kalitesi, tohum kalitesinin yanı sıra kullanılan ortam (Oliveira ve ark. 1993, Wagner Junior ve ark. 2006), rakım (Maciel ve ark. 2018), sıcaklık (Santos ve ark. 1999, Zucarelli ve ark. 2009) ve nem (Ospina ve ark. 1998) koşulları gibi faktörlerden de etkilenmektedir. Bu faktörler fidana dönüşüm zamanını ve dikim öncesi fidan kalitesini etkilemektedir.

Sıcaklık ve nem tohumların çimlenmesi ve fidan gelişimi için gereklidir (Santos ve ark. 1999, Braga ve Junqueira 2003, Zucarelli ve ark. 2009). Nem, kullanılan ortamın su tutma kapasitesine, su kalitesine, sulama tipine ve viyol tipine bağlı olarak fidanların gelişimini ve hastalıkların ortaya çıkmasını etkilemektedir. Sıcalık ise ortalama çimlenme süresi ve bitki gelişimi üzerine doğrudan etkilidir (Zucarelli ve ark. 2009). Ortam ve viyol tiplerinin de bitkilerin başlangıç gelişiminden itibaren fidan üretimi üzerine etkisi belirlenmiştir (Souza ve ark. 2006, Junqueira ve ark. 2014). 
Aşılı fidanlarda gelişim için ortam, besin maddesinin ulaşımına izin vermesinin yanı sıra, gözeneklilik, nem tutma kapasitesi, yetiştiricilik için uygun $\mathrm{pH}$, besin içeriği, katyon değişim kapasitesi, düşük tuzluluk gibi özelliklere sahip olmalıdır (Souza ve ark. 2006). Kullanılacak ortamın içeriği kum, bahçe toprağı, hindistan cevizi kabuğu, ticari kompostlar veya birkaç ortamın farklı oranlarda karıştırılmasından elde edilebilir. Fidan üretim kapları ise tüplü fidan üretiminde kullanılmakta ve farklı materyallerden farklı boyutlarda olabilmektedir (Şekil 3).
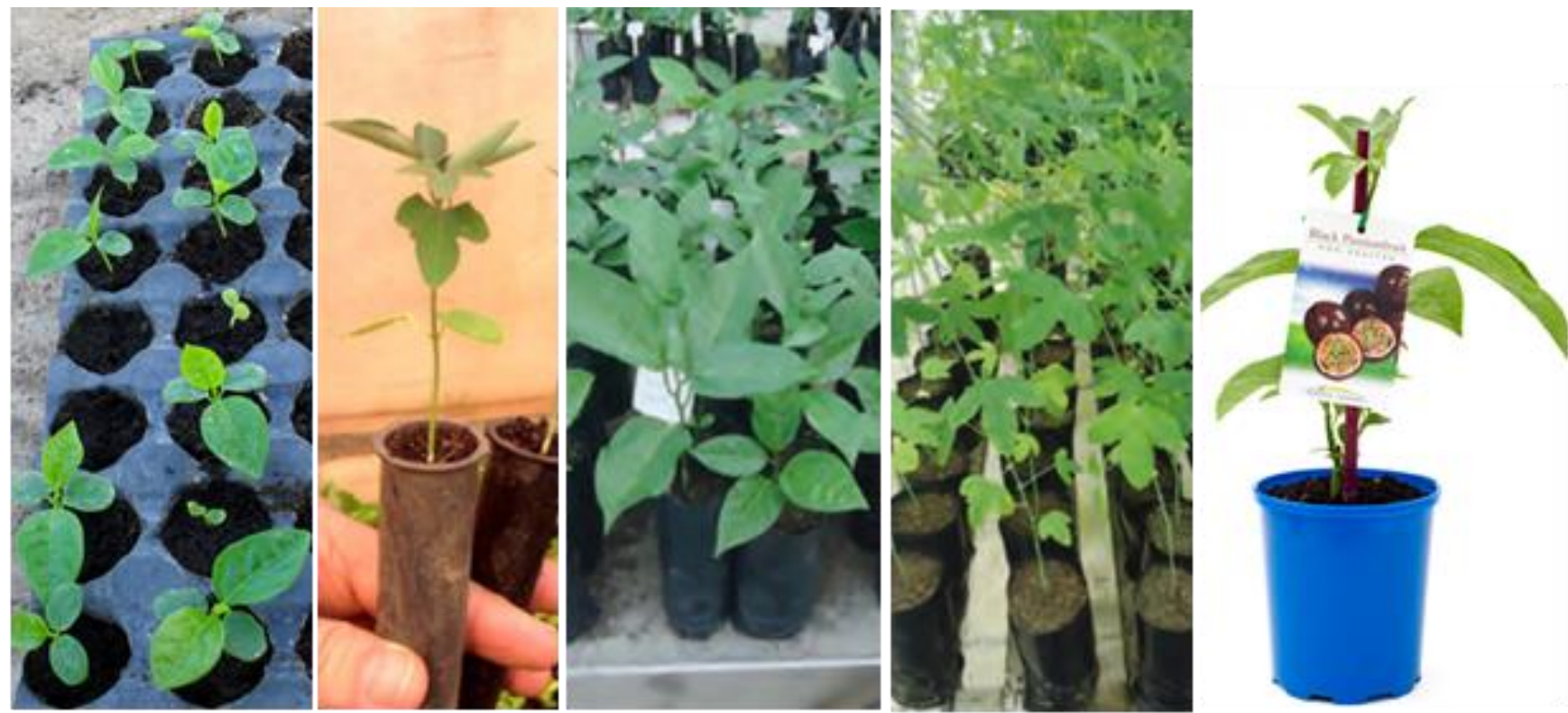

Şekil 3. Farklı kap boyut ve tiplerinde tohumdan çıkan farklı türlerden ( $P$. caerulea, $P$. edulis, $P$. gibertii) çarkıfelek fidanları

Nispeten büyük fidan üretim kapları üst aksam ve kök sistemi olarak daha büyük fidan gelişimine imkan verirken, küçük kaplar daha küçük alanlar istemesi ve fidanların ticari olarak taşınmasını kolaylaştırdığı için talep edilmektedir. Genel olarak, daha büyük ve pişkin fideler arazi koşullarında daha düşük bir ölüm oranı, zararlılara ve hastalıklara karşı daha yüksek tolerans (özellikle gelişimin başlangıcındaki en savunmasız aşamasında) ve daha yüksek verimlilik (çoğunlukla zararlı ve hastalık oranı yüksek olan bölgelerde) gösterirler. Bu avantajlara bağlı olarak, Junqueira ve ark. (2014) çarkıfelek türlerinde teknik ve ekonomik canlıık için fidanların $90 \mathrm{~cm}$ uzunluğunda olması gerektiğini bildirmiştir (Şekil 3).

\section{Vejetatif Çoğaltma}

Çarkıfelek türlerindeki genel prensipler ve uygulamalar Çarkıfelek türlerinin çoğu vejetatif olarak başarılı bir şekilde çoğaltılmasına rağmen, bu türlerden bazılarının çoğaltılması ticari olarak tohumla yapılmaktadır. Vejetatif çoğaltmanın temel avantajı klonal çoğaltmaya imkan sağlamasıdır. Vejetatif olarak çoğaltılan bireyler alındıkları anaç bitkinin birebir tüm özelliklerini gösterirler. Tatlı meyveli çarkıfelek, ekşi meyveli çarkıfelek (Passiflora edulis) ve yabani türlerde yüksek verimlilik, daha iri meyve hastalık ve zararlılara yüksek dayanım açısından klonal seleksiyonla üretilen fidanlar verimlilik ve birörnek kapama bahçe gibi önemli kazanımlar sağlamaktadır (Junqueira ve ark. 2006). Bununla birlikte çarkıfelek türlerinin çoğunun kendine uyuşmazlık gösterdiğini göz önünde bulundurmak gerekir. Sonuçta vejetatif olarak çoğaltılmış materyallerle çarkıfelek bahçesi kurulacaksa, tozlanma ve döllenmeyi garanti altına alabilmek için farklı bitkilerden alınmış çoğaltma materyalleri kullanılmalıdır. Çarkıfelek türlerinde fidan üretimi için çelik, aşı ve doku kültürü gibi vejetatif çoğaltma yöntemleri çoğunlukla kullanılmaktadır (Alexandre ve ark. 2009a). Bu yöntemlerin yanı sıra hobi amaçlı olarak daldırma ve dip sürgünleri ile çoğaltma yöntemleri de alternatif olabilir. Ancak bu vejetatif yöntemler, yüksek maliyetleri, kompleks olmaları, fidan üretimi için daha uzun süre istemeleri, yüksek teknolojili laboratuvar istemeleri, virüs hastalıklarından ari fidan eldesinin zor olması nedenleri ile ticari olarak türlerin çoğunda kullanılmamaktadır.

Kolombiya ve Brezilya gibi çarkıfelek üretiminde önemli ülkelerde yetiştirilen ana çeşitler çelikle çoğaltılmaktadır. Bu erken çiçeklenme (40-60 günde çiçeklenme), yüksek 
verimlilik, abiyotik ve biyotik stres koşullarına dayanım gibi çeşide ait önemli özelliklerin kazanılması açısından kullanılmaktadır. Özellikle süs bitkisi olarak kullanılan çeşitlerde çelikle çoğaltma tercih edilmektedir (Şekil 4).
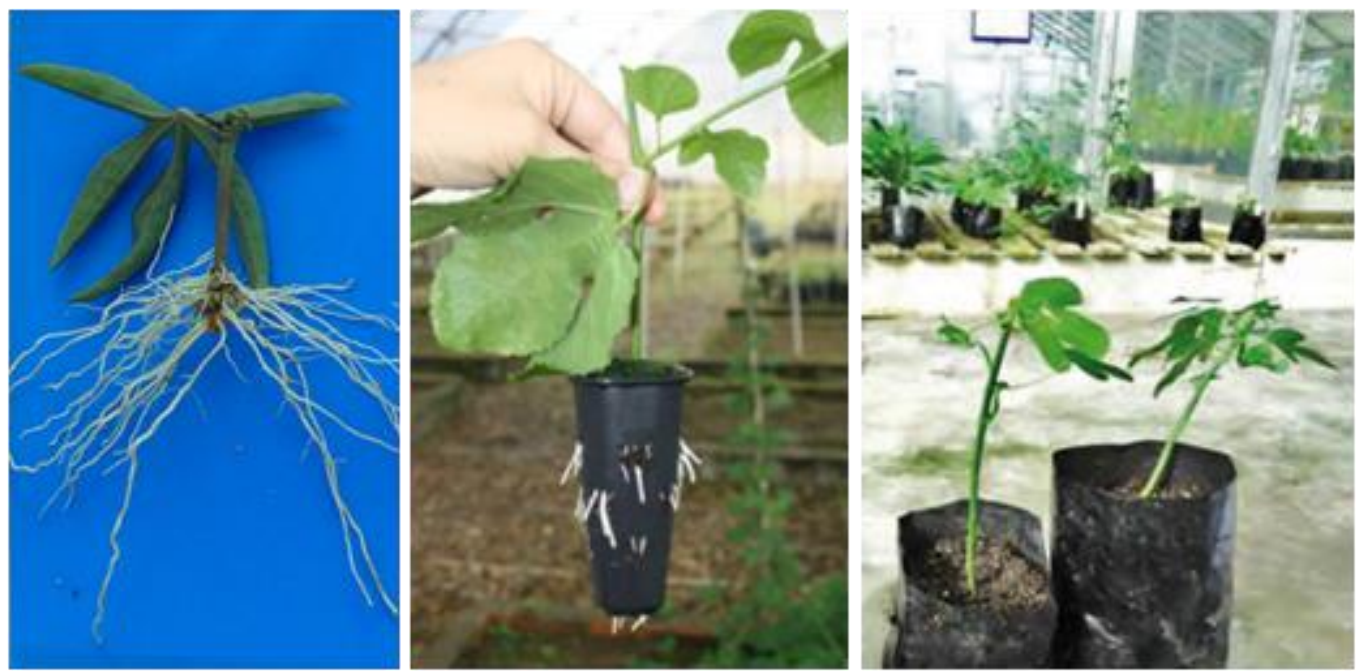

Şekil 4. Farklı tip ve türlerde çarkıfelek çelik köklendirme çalışmaları

Süs bitkisi olarak çarkıfelek üretiminde yeşil çeliklerle çoğaltma ile güçlü bitkiler ve yüksek köklenme oranı elde edildiği bildirilmiştir (Viana 2016). Koruma ve karakterizasyon programlarında ve genetik kaynakların kullanımında vejetatif çoğaltmanın önemini vurgulamak da önemlidir. Farklı çarkıfelek türlerine ait önemli genotipler Brezilya ve Kolombiya'daki araştırma enstitülerinde gen bankalarında ex situ olarak muhafaza edilmektedir. Ancak bazı türlerin tohumlarının rekalsitrant olması ve depolanmalarındaki bilgi eksikliği nedeniyle bu türlere ait genotiplerin genetik olarak korunmasının en iyi yolu seralarda, screenhouselarda ve açık kapama bahçelerde in vivo olarak muhafaza edilmeleridir. Vejetatif çoğaltma bu önemli genotiplerin klonlanmasına imkan vermektedir. $\mathrm{Bu}$ sayede genotiplerin genetik yapılarının devamlılığı ve aynı genotipe ait fazla sayıda fidanın üretilebilmesi sağlanır. Ayrıca elde edilen klonlanmış genotipler farklı gen bankalarında da muhafaza edilebilecektir.

Vejetatif çoğaltma, karakterizasyon çalışmalarında etkinliği artırarak, farklı çevre koşullarında genotiplerin istatistiksel olarak uygun şartlarda denenmelerine klonlanmış bitkiler sayesinde izin verdiği için ıslah çalışmaları açısından da önemlidir. Ayrıca klonlamaya imkan sağlaması nedeniyle tatlı ve ekşi çarkıfelek hibritlerinin meyve kalite özelliklerinin belirlenmesi için kurulacak denemelerde yeterli sayıda fidan eldesinde de vejetatif çoğaltma yöntemleri kullanılabilir. Seçilmiş ebeveynlerin veya anaç bireylerin klonlanarak çoğaltılmasında da vejetatif çoğaltma yöntemlerinin kullanılması avantajlar sağlamaktadır. Özellikle çelikle çoğaltma bireylerin klonlanmasında çarkıfelek türlerinde de başarıyla kullanılmaktadır.

\section{Çarkıfelek türlerinde çelikle çoğaltma}

Ticari ve yabani türlerde çelikle çoğaltma başarılı bir şekilde kullanılmaktadır. Ekşi (Passiflora edulis Sims) ve tatlı (Passiflora alata Curtis) çarkıfelek çeliklerinde köklenme ve çelikle üretim oranı $\% 90$ 'ın üzerinde belirlenmiştir (Salomao ve ark. 2002). Bu oranlar çelikle çoğaltma başarısının bir kanıtı olarak süs bitkisi olarak kullanılan çarkıfelek türlerinde de yüksektir (Viana 2016). Tür ve genotiplere göre farklı köklenme oranları elde edilmesine rağmen, farklı çarkıfelek türlerinde yapılan çalışmalarda (Paula ve ark. 2005, Braga ve ark. 2006, Roncatto ve ark. 2008a, Vaz ve ark. 2009) çelikle bu türlerde de fidan elde edilebileceğini göstermişlerdir. Bazı türler de IBA gibi bitki büyümeyi düzenleyiciler kullanılarak fidan üretim başarısı arttırılmaya çalışımıştır (Vaz ve ark. 2009, Viana 2016).

Başta türler ve türler arası hibritlerdeki genetik yapı olmak üzere çeliklerin köklenmesi üzerine birçok faktör etki etmektedir (Meletti ve Nagai 1992, Paula ve ark. 2005, Braga ve ark. 2006, Roncatto ve ark. 2008a, Vaz ve ark. 2009). Çarkıfelek türlerinde çevresel faktörlerden ortam farklılıkları ve kap boyutları da çeliklerin köklenmesini arttırmıştır (Oliveira ve ark. 1993, Junqueira ve ark. 2001, Silva ve ark. 2001, Oliveira ve ark. 2002, Rezende ve ark. 2005, Souza ve ark. 2006, Santos ve ark. 2012b). Ayrıca sentetik bitki büyümeyi düzenleyicilerin yanı sıra çelik alma zamanı (Uzunoğlu ve Mavi 2016), köklendirme ortamı (Melek Çağıl ve ark. 2018, Valle ve ark. 2018), kullanılan hormon dozu 
(Uzunoğlu ve Mavi 2017), köklenme ortamının sıcaklığı, kullanılan ortamın nem seviyesi ve kullanılan çelik tipininde köklenme üzerine etki ettiği belirlenmiştir (Rezende ve ark. 2005, Roncatto ve ark. 2008b, Vaz ve ark. 2009, Araujo ve ark. 2010).

Passiflora edulis çarkıfelek türünde yapılan çalışmalarda çeliklerin köklendirilebilmesinde ve köklenme oranlarında farklılıklar gözlemlenmiştir (Salamao ve ark. 2002, Paula ve ark. 2005). Açık olmayan bu sonuçlar yüzünden çelikle çoğaltma bazı türlerde önerilmemektedir. Bu çeşitlilik tür içerisindeki ana bitkinin biyokimyasal yapısı, beslenme durumu ve genetik çeşitliliğinden kaynaklanabilmektedir. Yine de çarkıfelek türlerinin çoğunda çelikle çoğaltma başarılı bir şekilde kullanılmaktadır. Bununla birlikte çeliklerin hazırlanma şekli, çelik alma zamanı, köklendirme ortamı, kullanılan hormon dozu, köklendirme ortamının sıcaklığı ve nemi ile ilgili farklı türlerde, genotiplerde ve çeşitlerde kullanılabilecek bir çarkıfelek çelik köklendirme protokolünün optimize edilmesi önerilebilir.

\section{Çarkıfelek türlerinde aşı ile çoğaltma}

Aşı ile çoğaltma anacın bazı önemli özelliklerinden yararlanmak için çok yıllık meyvelerde olduğu gibi çarkıfelek türlerinde de önemli bir çoğaltma yöntemidir. Aşılı fidan kullanımı ile toprak kökenli hastalıklara dayanım, soğuğa ve sıcağa dayanım, tuz, kireç ve su stresine dayanım sağlanabilmektedir. Bu özelliklerin yanı sıra fidanlar bir örneklik, yüksek verimlilik ve meyve kalitesinde artış gibi bitkisel özellikler açısından da bazı kazanımlar elde etmektedir (Maldonado 1991, Kishore ve ark. 2009, Machado ve ark. 2015, Salazar ve ark. 2016, Valle ve ark. 2018).

Toprak kökenli hastalıklardan en önemlisi ekşi çarkıfelek türünde çok ciddi zararlara yol açan Fusarium (Fusarium oxysporum f. sp. passiflorae ve Fusarium solani) çürüklüğüdür. Bu etmenlere karşı dayanıklı bir çeşit bulunmamaktadır. İlaçla mücadelesi de yoğun bulaşık alanlarda mümkün olmamaktadır. Sonuç olarak hastalık bulaşık kapama bahçelerde verim de azalmalara, bitkilerin erken kurumasına ve ekonomik kayıplara neden olmaktadır. Bu sorunlar nedeniyle Fusarium etmenli hastalıklar birçok araştırmacı tarafından problemlere çözüm sunmak amacıyla çalışılmıştır (Faleiro ve ark. 2006). Çalışmalar sonucunda araştırıcıların en çok odaklandıkları nokta hastalığa karşı yabani çarkıfelek türlerinin anaç olarak kullanılabilirliğinin değerlendirilmesidir (Junqueira ve ark. 2005, Junqueira ve ark. 2006, Cavachioli ve ark. 2009a, 2009b, Nogueira Filho ve ark. 2011, Roncatto ve ark. 2011, Semprebom ve ark. 2012, Machado ve ark. 2015).
En önemli çalışmalar, çarkıfelek yetiştiriciliğinde anaç olarak kullanılabilecek çeşit ve türlerin seçimi için yürütülmüştür. Bu çalışmalardaki en temel seçim kriteri toprak kökenli hastalıklara dayanım ve bitkilerin erken kurumasının önüne geçilmesidir. Anaçlarda kolay çoğaltılabilme, kalemle iyi uyuşma, hızı bir örnek gelişme ve yüksek verimlilik gibi özellikler aranmaktadır. $P$. nitida, $P$. alata, $P$. foetida, $P$. gibertii, $P$. setacea, $P$. cincinnata, $P$. caerulea, $P$. macrocarpa, $P$. quadrangularis, $P$. actinia, $P$. coccineave türler arası hibritler gibi bir çok çarkıfelek türü (Menezes ve ark. 1994, Oliveira ve ark. 1994, Oliveira ve Ruggiero 1998, Santos Filho 1998, Fisher 2003, Roncatto ve ark. 2004, Junqueira ve ark. 2005, Cavachioli ve ark. 2009a, Araujo ve ark. 2012, Semprebom ve ark. 2012, Silva 2016) istenilen özelliklerde bir anaç seçebilmek için çalışılmıştır. Altı çizilmesi gereken en önemli nokta çarkıfelek türlerindeki kadar Fusarium ırklarında da çok yüksek bir genetik çeşitlilik bulunmasıdır. Tek bir çarkıfelek genotipi veya türü tüm Fusarium etmenlerine karşı dayanıklılık göstermemektedir. Bu yüzden ticari bir anaç geliştirilmesi için çalışmalar sürdürülmektedir.

Başarılı bir aşı, anaç seçiminin yanında meyve kalitesi yüksek, verimli ve hastalıklara dayanıklı aşı kalemi olarak kullanılacak genotiplerin seçimine de bağlıdır. Kendine uyuşmazlık nedeniyle çiçeklenme ve meyve tutumu problemlerini azaltmak için aşı kalemlerinin faklı bitkilerden alınması gerekmektedir. Bu problem yüksek verimli çarkıfelek bahçelerinden aşı kalemleri alınarak azaltılabilir. Genellikle her bir aşı daha sonraki aşılar için önemli bir aşı kalemi anaçlık parseli olarak kullanılabilir. Farklı aşı tipleri, anaç kalem arasında uyuşmanın incelenmesi için çalışılmıştır. En çok kullanılan aşılama metotları kakma aşı ve dilciksiz (splice grafting) aşıdır (Machado ve ark. 2015). Kenar aşı (Side grafting), yanaştırma aşısı, hipokotiledon aşı (Ribeiro ve ark. 2008, Nogueira Filho ve ark. 2005, 2010, 2011, Santos ve ark. 2016b) ve mikro aşılama (Alexandre ve ark. 2013b) çarkıfelekte kullanımı konusunda çalışılmış diğer aşılama teknikleridir (Lima ve ark. 1999, Silva ve ark. 2005, Roncatto ve ark. 2011, Machado ve ark. 2015).

Ticari çarkıfelek türleri kullanıldığında anaç kalem arasındaki uyuşmayı sınırlandıran faktörlerden biri gövde çapları arasında farklılık bulunmasıdır. Bu problemin çözümündeki önemli bir teknik köklenmiş çeliklerin üzerine aşı yapılmasıdır. Anaç olarak klon çeliklerin kullanımı yüksek birörneklik nedeniyle tohumdan çıkan bireylere göre daha avantajlıdır (Junqueira ve ark. 2002, Chaves ve ark. 2004). Anaç kalem arasındaki çap farklıığını ortadan kaldırmanın bir diğer yolu hipokotiledon aşı tekniği olduğu bildirilmektedir (Şekil 5) (Nogueira Filho ve ark. 2005, 2010, Cavichioli ve ark. 
2009b, Santos ve ark. 2016b). Hipokotil aşı, yüksek aşı gelişimi ve tutma oranı gösterdiği ve farklı anaç ve aşı kombinasyonlarında kullanılabildiği için önerilmektedir (Santos ve ark. 2016b). Bu aşı tipinde kakma aşı tekniği kullanılmakta ve aşı bandı, plastik aşı klipsi, metal saç klipsi (Şekil 5) gibi farklı bağlama materyalleri başarılı bir şekilde uygulanabilmektedir (Santos ve ark. 2016b). Aşı klipsi kullanıldığı için hipokotil aşılama anaç birleştirme zamanının kısa olması, pratik, hızlı, kolay olması gibi avantajlara sahiptir. Ayrıca bu teknik aşı maliyetini de azaltmaktadır. Hipokotil aşı, yüksek aşı tutumu, hızlı aşı tutumu, yeni çıkış göstermiş fidelerde uygulanabilmesi, sağlıklı aşılı fidan üretimi sağlaması gibi avantajlara sahiptir. Diğer yandan hipokotil aşı tekniğinin ticari olarak kullanılabilmesi için üzerinde yapılan çalışmaların artırılmasına gerek vardır.
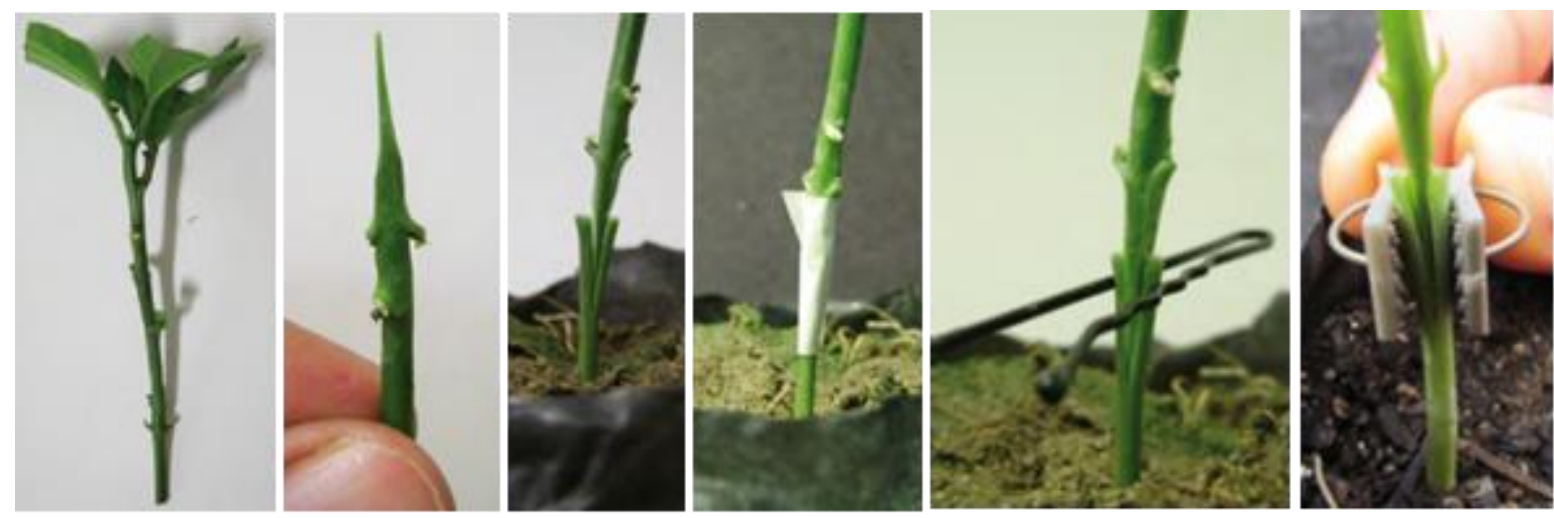

Şekil 5. Hipokotil aşı yapılışı ve kullanılan klips tipleri

Brezilya'da çarkıfelek aşılamada kullanılan teknoloji büyük bir ilgi ve potansiyele sahip olmasına rağmen, bu çoğaltma yönteminin, özellikle aşılamada kullanılacak anaçların bilimsel olarak henüz belirlenmemiş olması, aşılı bitkilerin yüksek maliyetli olması ve aşılı fidan üretiminin daha uzun süre gerektirmesinden dolayı ticari olarak kullanımı yaygın değildir. Son yıllarda, araştırma yoluyla elde edilen bazı sonuçlar ticari üretimde doğrulanmıştır. Bu çalışmalar sonucunda P. alata'nın, Rio de Janeiro'daki, $P$. nitida ve $P$. alata'nın Mato Grosso'daki, $P$. gibertii Bahia'daki ve $P$. foetida'nın Rio Grande do Norte'deki ticari fidan üretiminde anaç olarak kullanılması gerektiği belirlenmiştir (Machado ve ark. 2015). Bu konuda ülkemize uygun anaç ve türler üzerinde çalışılmalıdır.

\section{Doku Kültürü Yöntemleri}

Doku kültürü sebze üretimi başta olmak üzere birçok türde çok önemli bir klonal çoğaltma yöntemidir. Doku kültürü ile çok sayıda yeni çoğaltma materyali eldesi, genetik materyalin in vitro olarak korunması ve yüksek bitki sağlığına sahip aşılı fidan üretimi için klonal temizleme gerçekleştirilebilmektedir. Birçok çarkıfelek türünde farklı eksplant tipleri ve kültür ortamının kullanıldığı mikro çoğaltma yöntemlerine ilişkin birkaç literatür bulunmaktadır (Vieira ve ark. 2005, Ozarowski ve Thiem 2013, Otoni ve ark. 2013). Bununla birlikte, bu metodolojileri sınırlayan ana faktör, doku kültürü için geliştirilen bazı protokollerinin fide üretilebilirliği düşüktür, çünkü bunlar türlere ve bazen de çeşitlere özel geliştirilmiştir (Passos ve Bernanci, 2005). Bu sınırlamalar gen bankalarında genotiplerin korunmasında doku kültürü tekniklerinin kullanılması aşamasında tür ve genotiplerin farklı tepkiler verebilmesi nedeniyle daha da önemli hale gelmektedir.

Doğrudan veya dolaylı organogenesis, birçok büyüme düzenleyici kombinasyonu ve eksplant tipi kombinasyonu kullanarak çok sayıda çarkıfelek türünde başarıyla gerçekleştirilmiştir (Appezzato-da-Gloria ve ark. 1999, Vieira ve ark. 2005, Fernando ve ark. 2007, Garcia ve ark. 2011, Silva ve ark. 2011, Vieira ve ark. 2014). Ayrıca çarkıfelek türlerinde yapılan çalışmalarda somatik embriyogenesisde (Otoni ve ark. 1995, Anthony ve ark. 1999, Reis ve ark. 2007, Silva ve ark. 2009, Pinto ve ark. 2011, Rocha ve ark. 2012, 2015, Rosa ve ark. 2015, Pacheco ve ark. 2016) de önemli ilerlemeler kaydedilmiştir. Farklı çarkıfelek türlerinde organogenesis ve somatik embriyogenesisle doku kültüründen başarılı bir şekilde bitki üretimi sağlanmıştır (Şekil 6). 


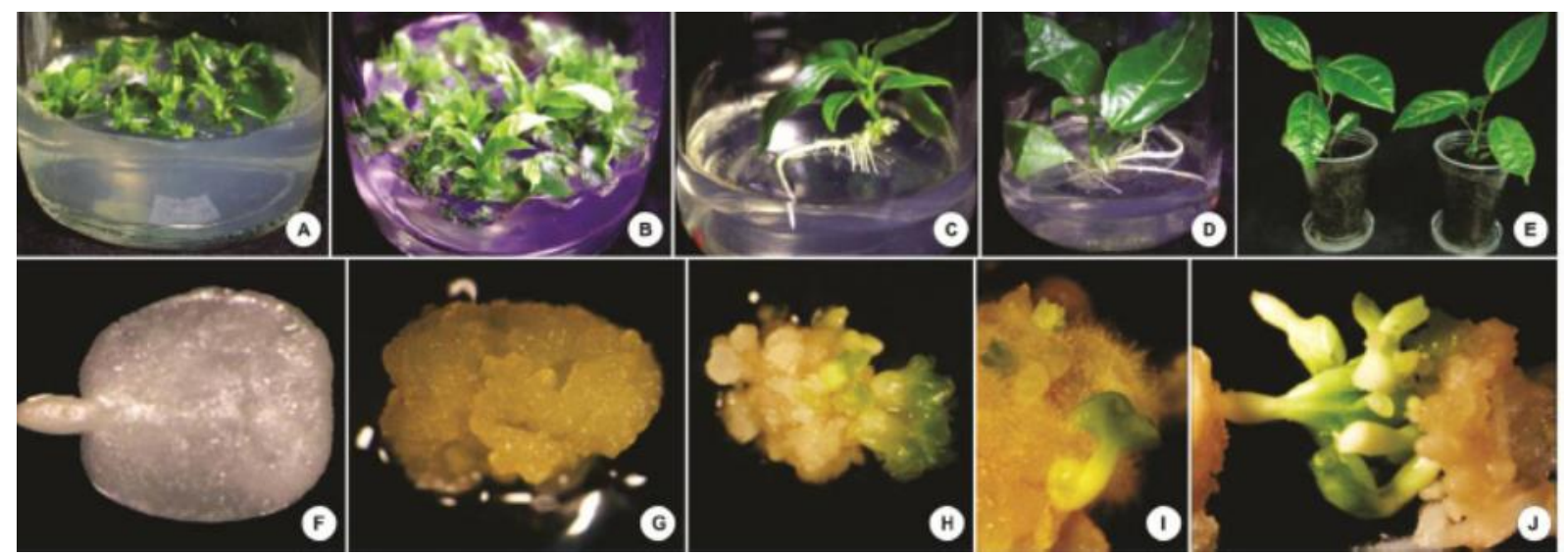

Şekil 6. P.edulis türünde kotiledon eksplantları kullanılarak adventif organogenesis (A-E), P. cincinnata türünde zigotik embriyodan somatik embriyogenesis (F-J)

In vitro çoğaltma, çarkıfelek türünde fidan tedarik zinciri için, özellikle süs bitkisi olanlarda bitkilerin güzelliği ve çiçek sayısı veya tıbbi kullanıma sahip olan türlerde şifalı bitkilerin üretimi ile ilgili genetik kimliğinin korunmasında da önem taşımakta ve büyük bir teknolojik potansiyel sunmaktadır (Pipino ve ark. 2008, Santos ve ark. 2010, Braglia ve ark. 2010, Ozarowski ve Thiem 2013). Ekşi, tatlı ve yabani çarkıfelek fidanlarının tedarik zincirlerinde, klonal mikro-çoğaltma yüksek bir potansiyele sahiptir, ancak klonal (vejetatif) yolla çoğaltılmaları nedeniyle, bir meyve bahçesi oluştururken kendine uyuşmazlık problemlerini önlemek için genetik olarak farklı bitkilere sahip farklı kaynaklardan alınan bitkilerden doku kültürü ile çoğaltma yapılmasına dikkat edilmelidir.

Doku kültürü ayrıca in vitro tohumların çimlenmesi ve embriyo kurtarma gibi yöntemlerle çarkıfelek çoğaltma konusunda yeni uygulamalarda sunmaktadır (Guzzo ve ark. 2011, Gonzales-Benito ve ark. 2009, Alexandre ve ark. 2009b). Doku kültürünün bir başka çok önemli kullanım alanı ise tatlı, ekşi, süs ve tıbbi amaçlı kullanılan çarkıfelek genotiplerinin elit ana bitkilerinin ve gen bankalarında tutulan örneklerin klonal olarak hastalıklardan arileştirilebilmesidir. Bu amaçla en çok kullanılan in vitro teknik meristem kültürü yöntemidir (Parmessur ve ark. 2002, Prammanee ve ark. 2011). Bu tekniğin prensibi, potansiyel olarak patojen içermeyen küçük ve hızlı gelişen sürgün ucu (apikal meristem) eksplantlar kullanılarak hazırlanmalarıdır. Bu yöntemlerle elde edilen bitkilerde çarkıfelek türlerinde kesin sonuçlarla klon temizliği için mikro aşılama teknikleri kullanılabilmektedir (Ribeiro ve ark. 2008).

Farklı çarkıfelek türlerinin üretim aşamasında doku kültürlerinde meydana gelen büyük teknolojik gelişmelere rağmen, aşılı bitkilerin üretiminde bu teknolojinin kullanımı ise halen yenidir. Bu nedenle, aşıların üretimi sırasında oluşabilecek maliyetleri ve somaklonal varyasyonları azaltma metodolojilerinin yanı sıra doku kültürü için uygun kültür ortamının oluşturulması için daha ileri düzeyde temel çalışmalar yapılması gerekmektedir.

\section{Çarkıfelek üretimi (çoğaltılması) için temel öneriler}

Brezilya, Arjantin, Kolombiya gibi ülkelerde farklı çarkıfelek türlerinin çoğaltılması ve yetiştirilmesine ilişkin önemli teknolojik ilerlemeler sağlanmıştır. Bununla birlikte, ticari potansiyeli olan çok sayıda tür ve özel melezin ve bunların ekşi, tatlı, süs ve fonksiyonel tıbbi bitki olarak çeşitlendirilmiş kullanımları göz önüne alındığında, araştırma ve geliştirme çalışmaları konusunda yapılması gereken çok şey olduğu söylenebilir.

Pek çok çarkıfelek türü için kısa süreli ve uzun süreli tohum depolanabilirliği ve depolama koşulları ve tohumların çimlenmesini etkileyen faktörler, generatif ve vejetatif çoğaltma protokol ve teknikleri tam olarak bilinmemektedir. Türler arasındaki farklııkların yanı sıra, her türün içindeki genotip ve çeşitler de tohum depolama, kalite ve çimlenme özelikleri açısından mutlaka araştırılması gerekmektedir.

Alternatif meyve türlerinin genetik kaynak olarak, ıslah programları açısından ve gıda sanayi açısından korunmalarındaki ve karakterizasyonlarındaki büyük önemleri göz önünde bulundurarak, ticari kullanıma sahip (ekşi, tatlı, süs ve tıbbi) çarkıfelek türleri için aşılı bitkilerin çoğaltılmasında kullanılan metodolojilerin optimize edilmesi amacıyla çalışılmalıdır. Bu süreci etkileyen sayısız faktör, farklı türler, genotipler ve çeşitler için maliyetleri düşürecek ve kullanılan yöntemin etkinliğini arttıracaktır.

Aşıyla vejetatif çoğaltma konusunda, topraktaki patojenlerin neden olduğu hastalıklara karşı dayanıkııık gösteren, su ve tuz stresine tolerans gösteren, hızlı bir büyüme ve yüksek aşı tutma başarısı sahip, kolay 
çoğaltılan, kalem ile uyumluluk gösteren anaçların seçimi, geliştirilmesi ve tescili konusunda çalışmalar yapılmalıdır. Aşılama yöntemleri açısından ise teknolojinin ekonomik olarak uygulanabilirliğini sağlayan ve maliyetleri azaltan aşı teknikleri üzerinde çalışmalar yapılmalıdır. Ticari şartlarda aşılı fidanlar özellikle bitkilerin erken ölümüyle sonuçlanan biyotik ve abiyotik stres geçmişi olan bölgelerde test edilmelidir.

Doku kültürü kısa sürede çok sayıda fidan eldesine ve hastalıklardan ari fidanların üretiminde çok önemli bir çoğaltma tekniğidir. Farklı doku kültürü tekniklerinin, çarkıfelek tür, çeşit ve genotiplerinin etkin bir şekilde çoğaltılmasında kullanılabilirliği ve doku kültürü protokolü oluşturma konusudaki çalışmalara da devam edilmelidir.

Sonuç olarak ülkemiz çafkıfelek üretiminin geliştirilebilmesi için ise adaptasyon çalışmaları ile farklı genotiplerin performansları belirlemek ve üstün verimli olan tiplerin çoğaltılması ve yetiştiricilik teknikleri üzerinde çalışmaların yapılması gerekmektedir. Süs ve tıbbi bitki olarak kullanılabilecek çarkıfelek tür ve tiplerin seçilmesi gereklidir. Ayrıca tozlayıcı kullanımı, tozlayıcı seçimi ve kapama bahçeler için kullanılması gereken tozlayıcı sayısı konusunda da çalışılmalıdır.

\section{ÖZET}

Amaç: Bu derleme ülkemizde yeni bir bitki türü olarak farklı özellikleri nedeniyle gelişme göstereceği düşünülen çarkıfelek türlerinin çoğaltma teknikleri konusunda hazırlanmıştır.

Yöntem ve Bulgular: Bu derleme ile çarkıfelek türünün farklı çoğaltma yöntem ve uygulamaları konusunda bilimsel ve teknolojik gelişmeler dikkate alınarak bilgi verilmiştir.

Genel Yorum: Çarkıfelek türlerinde vejetatif çoğaltma yöntemleri ve generatif çoğaltma yöntemi kendi içerisinde avantaj ve dezavantajlara sahiptir.

Çalışmanın Önemi ve Etkisi: Neticede çok zengin bir tür çeşitliliği olan ve gıda, süs bitkisi ve tıbbi bitki olarak kullanımı olan bu cinsin, araştırma ve geliştirme faliyetlerine yönelik yeni talepler başarılı bir şekilde çoğaltılabilmelerine bağlıdır. Bu derleme ile çarkıfelek çoğaltma teknikleri detaylı olarak açıklanmıştır.

Anahtar Kelimeler: Süs bitkisi, tıbbi bitki, alternatif meyve.

\section{ÇIKAR ÇATIŞMA BEYANI}

Yazar(lar) çalışma konusunda çıkar çatışmasının olmadığını beyan eder.

\section{ARAŞTIRMACILARIN KATKI ORANI BEYANI}

Yazarlar çalışmaya eşit oranda katkı sağlamış olduklarını beyan eder.

\section{KAYNAKLAR}

Abreu PP, Souza MM, Santos EA, Pires MV, Pires MM, De Almeida AF (2009) Passion Xower hybrid sand their use in the ornamental plant market: perspectives for sustainable development with emphasis on Brazil. Euphytica, 166(3): 307-315.

Aguacía LM, Miranda D, Carranza C (2015) Effect of fruit maturity stage and fermentation period on the germination of passion fruit (Passiflora edulis $\mathrm{f}$. flavicarpa Deg.) and sweet granadilla seeds (Passiflora ligularis Juss.). Agronomía Colombiana, 33(3): 305-314.

Alexandre RS, Bruckner CH, Lopes JC (2009a) Propagação do maracujazeiro: aspectos morfológicos, fisiológicos e genéticos. Alegre: EDUFES, 208p.

Alexandre RS, Couto FAD, Dias JMM, Otoni WC, Cecon PR, Gomes BS (2009b) Factors affecting in vitro germination of passion fruit seeds. Plant Cell Culture and Micropropagation 5: 27- 35.

Alexandre RS, Ferrari WR, Monteiro Junior KR., Chagas K, Schmildt ER, Gontijo I (2013a) Enraizamento de estacas de genótipos de Passiflora alata Curtis emrespostaaausência e presença de ácido indol-3butírico (AIB). Revista Ciência Agraria, 56: 287-291.

Alexandre RS, Lopes JC, Tiradentes AT, Bruckner $\mathrm{CH}$, Otoni WC (2013b) Metodologia de minienxertia em maracujazeiros. Revista Brasileira de Fruticultura, 35: 329-332.

Alexandre RS, Costa PR, Chagas K, Mayrinck LG, Giles JAD, Schmildt E.R. 2016. Different propagules and auxin concentration on rooting of passion flower sandbank. Revista Ceres 63: 589-592.

Alexandre RS, Júnior AW, Negreiros JRS, Parizzotto A, Bruckner CH (2004) Seed germination of yellow passion fruit genotypes. Pesquisa Agropecuária Brasileira, 39: 1239-1245.

Anthony P, Otoni WC, Power JB, Lowe KC, Davey MR (1999) Protoplast isolation, culture, and plant regeneration from Passiflora. In: Hall RD (Ed.). Plant cell culture protocols. Wageningen: Humana Press, 169-181.

Appezzato-da-Glória B, Vieira MLC, Dornelas MC (2007) Anatomical studies of in vitro organogenesis induced in leaf-derived explants of passionfruit. Pesquisa Agropecuária Brasileira, 34: 2007-2013. 
Araujo CAT, Faleiro FG, Semprebom MS, Krause W (2012) Sobrevivência de plantas enxertadas de maracujazeiro em área com histórico de doenças causadas por Fusarium spp.no Mato Grosso. In: Congresso Brasıleıro De Frutıcultura, 22, Bento Gonçalves. Anais.4p.

Araujo FP, Mouco MAC, Ono EO, Rodrigues JD (2010) Substratos e concentrações de ácido indolibutírico no enraizamento de estacas de Passiflora cincinnata Mast. Magistra, 22(1): 21-27.

Bernacci LC, Soares-Scott MD, Junqueira NTV, Passos IRDS, Meletti LMM (2008) Passiflora edulis Sims: the correct taxonomic way to cite the yellow passion fruit (and of otherscolors). Revista Brasileira de Fruticultura, 30(2):566-576.

Braga MF, Junqueira NTV (2003) Produção de mudas de maracujá-doce. Planaltina, DF: Embrapa Cerrados, $28 p$.

Braga MF, Santos EC, Junqueira NTV, Sousa AATC, Faleiro FG, Rezende LN, Junqueira KP (2006) Enraizamento de estacas de três espécies silvestres de Passiflora. Revista Brasileira de Fruticultura, 28(2): 284-288.

Braglia L, Benedetti L, Giovannini A, Nicoletti F, Bianchini C, Pipino L, Mercuri A (2010) In vitro plant regeneration as a tool to improve ornamental characters in Passiflora species. Acta Horticulturae, 855: 47-52.

Bruckner CH, Casali Moaraes VWD, Ragazzi AJ, Silva EMA (1995) Self incompatibility in Passion Fruit (Passiflora edulis Sims). Acta Horticulturae, 370: 45-57.

Cavichioli JC, Correa LS, Boliani AC (2009a) Sobrevivência e desenvolvimento de seis espécies de maracujazeiros em área com histórico de morte prematura de plantas. Cultura Agronômica, 18: 6773.

Cavichioli JC, Corrêa LS, Boliani AC, Oliveira JC (2009b) Uso de câmara úmida em enxertia hipocotiledonar de maracujazeiro-amarelo sobre três porta-enxertos. Revista Brasileira de Fruticultura, 31: 532-538.

Cerqueira-Silva CB, Faleiro FG, De Jesus ON, Santos ESL, Souza AP (2018) Passion fruit (Passiflora spp.) breeding. Advances in Plant Breeding Strategies: Fruits, Volume 3, Ed. Al-Khayri J.M., Jain S.M., Johnson D.V., p. 929-951.

Cerqueira-Silva CB, Jesus ON, Santos ESL, Corrêa RX, Souza AP (2014) Genetic Breeding and diversity of the genus Passiflora: Progress and perspectives in molecular and genetic studies. International Journal of Molecular Sciences, 15: 14122-14152.
Chaves RC, Junqueira NTV, Manica I, Peixoto JR, Pereira AV, Fialho JF (2004) Enxertia de maracujazeiro-azedo em estacas herbáceas enraizadas de espécies de passifloras nativas. Revista Brasileira de Fruticultura, 26: $120-123$.

Coelho de Araújo E, Figueiredo Daher R, Ferreira da Silva R, Pio Viana A (2007) Path analysis for physiological traits that influence seed germination of Passiflora edulis f. flavicarpa Deg. Crop Breeding and Applied Biotechnology, 7: 148-154.

Costa AM, Lima HC, Cardoso ER, Silva JR, Padua JG, Faleiro FG, Pereira RCA, Campos GA (2015). Produção de mudas de maracujazeiro silvestre (Passiflora setacea). Planaltina, DF: Embrapa Cerrados, 6p.

Delanoy M, Van Damme P, Scheldeman X, Beltran J (2006) Germination of Passiflora mollissima (Kunth) L.H. Bailey, Passiflora tricuspis Mast. and Passiflora nov sp. seeds. Scientia Horticulturae, 110: 198-203.

Ellis RT, Hong TD, Roberts EH (1985) Hand book of seed technology for genebanks. Roma: International Board for Plant Genetic Resources, p. 456.

Faleiro FG, Junqueira NTV, Costa AM, De Jesus ON, Machado CF (2017) Instituto Interamericano de Cooperaciónpara la Agricultura (IICA),Maracujá.p.31.

Faleiro FG, Junqueira NTV, Junghans TG, De Jesus ON, Miranda D, Otoni WC (2019) Advances in passion fruit (Passiflora spp.) propagation. Revista Brasileira de Fruticultura, 41(2): 150-155.

Faleiro FG, Junqueira NTV, Braga MF (2006) Maracujá: demandas para a pesquisa. Planaltina, DF: Embrapa Cerrados, p.54.

Fernando JA, Vieira MLC, Machado SR, Appezzato-daGlória B (2007). New insights into the in vitro organogenesis process: the case of Passiflora. Plant Cell Tissue and Organ Culture, 91: 37- 44.

Ferrreira G (2000) Propagação do maracujazeiro. Rev. Inf. Agropec., 21:18-24.

Garcia R, Pacheco G, Falcao E, Borges G, Mansur E (2011) Influence of type of explant, plant growth regeneration, salt composition of basal medium, and light on callogenesis and regeneration in Passiflora suberosa (Passifloraceae). Plant Cell Tissue and Organ Culture, 106: 47-54.

Gonzales-Benito ME, Aguila N, Avila T (2009) Germination and embryo rescue from Passiflora species seeds post-cryopreservation. CryoLetters, 30: 142-147.

Grisi MCM, Faleiro GF, Junqueira NTV, Oliveira JS (2019) Genetic variability of passion fruit multispecific hybrids and their respective wild parents determined by microsatellite markers. Journal of Agricultural Science, 11(10): 302-312. 
Grzybowski CRS, Da Silva RC, Belniaki AC, Panobianco M (2019) Investigation of dormancy and storage potential of seeds of yellow passion fruit. Journal of Seed Science, 41(3): 367-374.

Guzzo F, Ceoldo S, Andreatta F, Levı M (2011) In vitro culture from mature seeds of Passiflora species. Scientia Agricola, 61: 108-113.

Junqueira NTV, Lage DA, Braga MF, Peixoto JR, Borges TA, Andrade SRM (2006) Reação a doenças e produtividade de um clone de maracujazeiro-azedo propagado por estaquia e enxertia em estacas herbáceas de Passiflora silvestre. Revista Brasileira de Fruticultura, 28: 97-100.

Junqueira NTV, Manica I, Chaves RC, Lacerda CS, Oliveira JA, Fialho JF (2001) Produção de mudas de maracujazeiro-azedo por estaquia em bandejas. Planaltina, DF: Embrapa Cerrados, (Recomendações Técnicas, 42).

Junqueira NTV, Zacaroni $A B$, Souza MA, Faleiro FG, Teixeira LP (2014) Custo e estimativa de produtividade obtidos a partir de mudas de maracujazeiro-azedo tipo 'mudão' com diferentes idades. In: Congresso Brasileiro De Fruticultura, 23.

Junqueira NTV, Chaves RC, Manıca I, Peixoto JR, Pereıra AVE, Fialho JF (2002) Propagação do maracujazeiro azedo por enxertia em estacas herbáceas enraizadas de espécies de passifloras nativas. Planaltina: Embrapa Cerrados, 15p. (Boletim de Pesquisa e Desenvolvimento, 39).

Junqueira NTV, Braga MF, Faleıro FG, Peixoto JR, Bernacc LC (2005) Potencial de espécies silvestres de maracujazeiro como fonte de resistência a doenças. In: Faleıro, F.G., Junqueıra NTV, Braga MF (Ed.). Maracujá: germoplasma e melhoramento genético. Planaltina, DF: Embrapa Cerrados, p.81-108.

Kishore K, Pathak KA, Sukhla R (2009) Soft wood grafting in purple passion fruit. Indian Journal of Agricultural Sciences, 79(6): 473-476.

Kuhne FA (1968) Cultivation of gradanillas. Farming in South Africa, 43: 29-32.

La Rosa AM (1984) The biology and ecology of Passiflora mollissima in Hawaii. Cooperative National Park Resources Studies Unit. Technical report 50.

Leonel S, Pedroso CJ (2005) Produção de mudas de maracujazeirodoce com o uso de biorregulador. Revista Brasileira de Fruticultura, 27(1): 107-109.

Lima AA, Caldas RC, Cunha MAP, Santos Filho HP (1999) Avaliação de porta-enxertos e tipos de enxertia para - maracujazeiro-amarelo. Revista Brasileira de Fruticultura, 21(3): 318- 321.
Machado CF, Faleiro FG, Junqueira NTV, Jesus ON, Araújo FP, Girardi EA (2015) A enxertia do maracujazeiro: técnica auxiliar no manejo fitossanitário de doenças do solo. Cruz das Almas, BA: Embrapa Mandioca e Fruticultura, 15p. (Circular Técnica, 116).

Maciel KS, Lima PAM, Madalon FZ, Paiva S, Moraes CB, Alexsandre RS, Lopes JC (2018) The physiological quality of the seeds of passion fruit (Passiflora spp.) grown at different altitudes. Australian Journal of Crop Science, 12(6): 937-942.

Maldonado JFM (1991) Utilização de porta-enxertos do gênero Passiflora para maracujazeiro-amarelo (Passiflora edulis Sims f. flavicarpa Deg.). Revista Brasileira de Fruticultura, 13: 51-54.

Marostega TN, Da Luz PB, Tavares AR, Neves LG, Sobrinho SP (2017) Methods of breaking seed dormancy for ornamental passion fruit species. Ornamental Horticulture, 23(1):72-78.

Melek Çağıl H, Uzunoğlu F, Mavi K (2018) Faklı köklendirme ortamlarının pasiflora bitkisinde çelik köklenmesi üzerine etkileri. Bahçe, 47(Özel sayı 2): 289-294.

Meletti LMM (2011) Avançosna cultura do maracujáno Brasil. Revista Brasileira de Fruticultura, 33(1): 83-90.

Meletti LMM, Barbosa W, Veiga RFA, Pior R (2007) Crioconservação de sementes de seisacessos de maracujazeiro. Revista Scientia Agrária Paranaensis, 6: 13-20.

Meletti LMM, Nagai V (1992) Enraizamento de estacas de sete espécies de maracujazeiro (Passiflora spp). Revista Brasileira de Fruticultura, 14(2): 163-168.

Menezes JMT, Oliveira JC, De Ruggiero C, Banzatto DA (1994) Avaliação da taxa de pegamento de enxertos de maracujá-amarelo sobre espécies tolerantes à “morte prematura de plantas". Científica,22: 95-104.

Miranda D, Carranza C, Cardenas J, Rodriguez A, Gutierrez I (2013) Estado actual de la investigación en la propagación de Pasifloras en Colombia. In: Carranza C., Ocampo J., Miranda D., Parra M., Castillo J., Rodriguez A. Libro de Memorias-Congreso Latinoamericano de Pasifloras. Neiva: Corporación Cepass Colombia, 1: 72- 86.

Miranda D, Fisher G, Carranza C, Magnitskiy S, Casierra F, Piedrahita W, Florez LH (2009) Cultivo, poscosecha, y comercialización de laspasifloráceas en Colombia: maracuyá, granadilla, gulupa y curuba. Bogotá: Sociedad Colombiana de Ciencias Horticolas, 51p.

Morley-Bunker MJS (1980) Seed coat dormancy in Passiflora species. Annual Journal of the Royal New Zeland Institute of Horticulture, 8: 72- 84. 
Nave N, Katz E, Chayut N, Gazit S, Samach S (2010) Flower development in the passion fruit Passiflora edulis requires a photoperiod-induced systemic grafttransmissible signal. Plant, Cell and Environment, 33: 2065-2083.

Negreiros JRS, Wagner Junior A, Alvares VS, Silva JOC, Nunes ES, Alexxandre RS, Pimentel LD, Bruckner CH (2006) Influência do estádio de maturação e do armazenamento pós-colheita na germinação e desenvolvimento inicial do maracujazeiro-amarelo. RevistaBrasileira de Fruticultura, 28: 21-24.

Nogueira Filho GC, Roncatto G, Ruggieiro C, Oliveira JC, De Malheiros EB (2005) Propagação vegetativa do maracujazeiro-conquista de novas adesões. In: Faleiro FG, Junqueıra NTV, Braga MF (Ed.). Maracujá: germoplasma e melhoramento genético. Planaltina, DF: Embrapa Cerrados, p.341-358.

Nogueira Filho GC, Roncatto G, Ruggiero C, Oliveira JC, Malheiros EB (2010) Estudo da enxertia Hipocotiledonar do maracujazeiro-amarelo sobre dois porta-enxertos, através da microscopia de varredura. Revista Brasileira de Fruticultura, 32: 647652.

Nogueira Filho GC, Roncatto G, Ruggiero C, Oliveira JC, Malheiros EB (2011) Produção de mudas de maracujazeiro-amarelo por enxertia hipocotiledonar sobre sete espécies de passifloras. Revista Brasileira de Fruticultura, 33(1): 237- 245.

Oliveira Junior MX, São José AR, Rebouças TNH, Morais OM, Dourado FWN (2010) Superação de dormência de maracujá-do-mato (Passiflora cincinnata MAST.). Revista Brasileira de Fruticultura, 32(2): 584-590.

Oliveira RP, Scivittaro WB, Vasconcellos LABC (1993) Avaliação de mudas de maracujazeiro em função do substrato e do tipo de bandeja. ScientiaAgrícola, 50(2): 261- 266.

Olıveira JA, Junqueira NTV, Peixoto JR, Pereira AV (2002) Efeito dos substratos artificiais no enraizamento e no desenvolvimento de estacas de maracujazeiro-azedo (Passiflora edulis Sims f. flavicarpa Deg.). Revista Brasileira de Fruticultura, 24: 505-508.

Olıveira JC, Ruggiero C (1998) Aspectos sobre o melhoramento do maracujazeiro amarelo. In: Ruggiero C (Ed.). Maracujá:do plantio à colheita. Jaboticabal: FUNEP, p.291-310.

Oliveira JC, Nakamura K, Mauro AO, Cunha MAP (1994) Aspectos gerais do melhoramento do maracujazeiro. In: Sao Jose, A.R. Maracujá: produção e mercado. Vitória da Conquista: DFZ-UESB, p.27-37.
Ospina JA, Guevara CL, Caicedo LE, Barney V (1998) Effects of moisture on Passiflora seed viability after immersion in liquid nitrogen. In: Engelmann F., Hiroko T. (Ed.). Cryopreservation of tropical plant germplasm: current research progress and application japan international research center for agricultural sciences. Tsukuba: Japan International Research Center for Agricultural Sciences, p.384-388.

Ospina-Torres R, Jaramillo J, Rodriguez CA, Henao MM, Nates-Parra G (2018) Passion fruit in Colombia. Ed. David Ward Roubik, The Pollination of Cultivated Plants a Compendium for Practitioners Volume 1. FAO, Rome.

Otoni WC (1995) Hibridização e embriogênese somática e transformação genética em espécies de Passiflora. Tese (Doutorado em Genética e Melhoramento)Universidade Federal de Viçosa. p 198.

Otoni WC, Paım PInto DL, Rocha DI, Vieıra LM, Dias LLC, Silva ML, Silva CV, Lanı ERG, Silva LC, Tanaka FAO (2013) Organogenesis and somatic embryogenesis in passion fruit (Passiflora sps.). In: Aslam J, Srivastava OS, Sharma MP (Ed.). Somatic embryogenesis and gene expression. New Delhi: Narosa Publishing House. p. 1-17

Ozarowski M, Thiem B (2013) Progress in micropropagation of Passiflora spp. to produce medicinal plants: a mini-review. Revista Brasileira de Farmacognosia,23: 937-947.

Pacheco G, Simão MJ, Vianna MG, Garcia RO, Vieira MLC, Mansur E (2016) In vitro conservation of PassifloraA review. Scientia Horticulturae, 211: 205-311.

Padua JG, Schwingel LC, Mundim RC, Salomao AN, Roverijose SCB (2011) Emergência de sementes de Passiflora setaceae dormência induzida pelo armazenamento. Revista Brasileira de Sementes, 33(1): 80-85.

Parmessur Y, Aljanabı S, Saumtally S, Dookun-Saumtally A (2002) Sugarcane yellow leaf virus and sugarcane yellows phytoplasma: elimination by tissue culture. Plant Pathology, 51: 561-566.

Passos IRS, Matos GVC, Meletti LMM, Soares-Scott MD, Bernacci LC, Vieira MAR (2004) Utilização do ácido giberélico para a quebra de dormência de sementes de Passiflora nitida Kunth germinadas in vitro. Revista Brasileira de Fruticultura, 26(2): 380-381.

Passos IRS, Bernacci LC (2005) Cultura de tecidos aplicada à manutenção de germoplasma in vitro e ao melhoramento genético do maracujá (Passiflora spp.) In: Faleıro FG, Junqueıra NTV, Braga MF (Ed.). Maracujá: germoplasma e melhoramento genético, p.361-383. 
Paula MS, Faleiro FG, Junqueira KP, Bellon G, Junqueira NTV, Braga MF, Peixoto JR (2005) Diversidade genética de espécies de Passiflora, potenciais fontes de resistência a doenças, com base em marcadores RAPD. In: Faleiro FG, Junqueira NTV, Braga MF, Pinto ACQ, Sousa ES (Eds.) IV Reunião Técnica de Pesquisas em Maracujazeiro - Trabalhos apresentados. Planaltina, DF: Embrapa Cerrados, p. 100-104.

Pereira KJC, Dias DCFS (2000) Germinação e vigor de sementes de maracujá-amarelo (Passiflora edulis Sims. f. flavicarpa Deg.) submetidas a diferentes métodos de remoção da mucilagem. Revista Brasileira de Sementes, 22: 288-291.

Pinto DLP, Almeida AMR, Rêgo MM, Silva ML, Oliveira EJ, Otoni WC (2011) Somatic embryogenesis from mature zygotic embryos of commercial passion fruit (Passiflora edulis Sims) genotypes. Plant Cell, Tissue and Organ Culture, 107: 521-530.

Pipino L, Braglia L, Giovannini A, Fascella G, Mercuri A (2008) In vitro regeneration of Passiflora species with ornamental value. Propagation of Ornamental Plants,8: 47-49.

Pires MC, Peixoto JR, Yamanishi OK (2011) Rooting of passion fruit species with Indole-3-Butyric Acid under intermittent misting conditions. Acta Horticulturae, 894: 174-184.

Prammanee S, Thumjamras $\mathrm{S}$, Chiemsombat $\mathrm{P}$, Pipattanawong N (2011) Efficient shoot regeneration from direct apical meristem tissue to produce virusfree purple passion fruit plants. Crop Protection, 30: 1425-1429.

Rego MM, Rego ER, Nattrodt LPU, Barroso PA, Finger FL, Otoni WC (2014) Evaluation of different methods to overcome in vitro seed dormancy from yellow passion fruit. African Journal of Biotechnology, 13(36): 3657-3665.

Reis LB, Silva ML, Lima ABP, Oliveira MLP, Paim-Pinto DL, Lani ERG, Otoni WC (2007) Agrobacterium rhizogenes-mediated transformation of passionfruit species: Passiflora cincinnata and P.edulis $f$. flavicarpa. Acta Horticulturae, 738: 425-431.

Rezende OP, Pimentel LD, Alves TL, Morgado MAD (2005) Estaquia de maracujá amarelo (Passiflora edullis sims f. flavicarpa Deg.) em miniestufas constituídas de garrafas de poliestireno, avaliando-se cinco substratos. Revista Ceres, 52: 267-273.

Ribeiro LM, Peixoto JR, Andrade SRM, De Fonseca RS, Vieira LM, Pereira WVS (2008) Microenxertia ex vitro para eliminação do vírus CABMV em maracujá-azedo. Pesquisa Agropecuária Brasileira, 43: 589-594.
Rocha DI, Monte-Bello CC, Dornelas MC (2015) Alternative induction of de novo shoot organogenesis or somatic embryogenesis from in vitro cultures of mature zygotic embryos of passion fruit (Passiflora edulis Sims) is modulated by the ratio between auxin and cytokinin in the medium. Plant Cell Tissue and Organ Culture, 120: 1087-1098.

Rocha DI, Vieira LM, Tanaka FA, Silva LC, Otoni WC (2012) Somatic embryogenesis of a wild passion fruit species Passiflora cincinnata Masters: histocytological and histochemical evidences. Protoplasma, 249: 747-758.

Roncatto G, Nogueira Filho GC, Ruggiero C, Oliveira JC, Martins ABG (2008a) Enraizamento de estacas de espécies de maracujazeiro (Passiflora spp.) no inverno e no verão. Revista Brasileira de Fruticultura, 30(4): 1089-1093.

Roncatto G, Assis GML, Oliveira TK, Lessa LS (2011) Aspectos vegetativos de combinações copa/ portaenxerto em maracujazeiro. Revista Brasileira de Fruticultura, 33(3): 791-797.

Roncatto G, Nogueira Filho GC, Ruggiero C, Oliveira JC, Martins ABG (2008b) Enraizamento de estacas herbáceas de diferentes espécies de maracujazeiro. Revista Brasileira de Fruticultura, 30(4): 1094-1099.

Roncatto G, Oliveira JC, Ruggiero C, Nogueira Filho GC, Centurion MAPC, Ferreira FR (2004) Comportamento de maracujazeiros (Passiflora spp.) quanto à morte prematura. Revista Brasileira de Fruticultura, 26(3): 552- 554.

Rosa YBCJ, Monte Bello CC, Dornelas MC (2015) Speciesdependent divergent responses to in vitro somatic embryo induction in Passiflora spp. Plant Cell, Tissue and Organ Culture, 120: 69-77.

Salazar A., Ramirez C (2017) Fruit maturity stage and provenance affect seed germination of Passiflora mollissima (banana passion fruit) and $P$. ligularis (sweet granadilla), two commercially valuable tropical fruit species. Seed Science and Technology, 45(2): 383-397.

Salazar AH, Silva DFP, Bruckner CH (2016) Effect of two wild rootstocks of genus Passiflora $\mathrm{L}$. on the content of antioxidants and fruit quality of yellow passion fruit. Bragantia, 75(2): 164-172.

Salomao LCC, Pereira WE, Duarte RCC, Siqueira DLD (2002) Propagação por estaquia dos maracujazeiros doce (Passiflora alata Dryand.) e amarelo (P.edulis $\mathrm{f}$. flavicarpa Deg.). Revista Brasileira de Fruticultura, 24(1): 163-167. 
Santos Filho HP (1998) Doenças do sistema radicular do maracujazeiro. In: Sımpósıo Brasıleıro Sobre A Cultura Do Maracujazeıro, 5., Jaboticabal. Anais. Jaboticabal: Funep, p.244-254.

Santos MC, Sousa GRL, Silva JR, Santos VLM (1999) Efeito da temperatura e do substrato na germinação de sementes de maracujá (Passiflora edulis Sims. var. flavicarpa Deg.). Revista Brasileira de Sementes, 21: 1-6.

Santos FC, Ramos JD, Pasqual M, Rezend JC, Santos FC, Villa $F$ (2010) Micropropagação do maracujzaeiro do sono. Revista Ceres, 57: 112-117.

Santos JL, Matsumoto SN, D'arede LO, Luz ISD, Viana AES (2012b) Vegetative propagation of cuttings of Passiflora cincinnata Mast. in different commercial substrates and containers. Revista Brasileira de Fruticultura, 34(2): 581-588.

Santos TM, Flores PS, Oliveira SP, Silva DFPS, Bruckmer $\mathrm{CH}$ (2012a) Tempo de armazenamento e métodos de quebra de dormência em sementes do maracujá-derestinga. Revista Brasileira de Agropecuária Sustentável, 2(1): 26-31.

Semprebom MS, Faleiro FG, Araujo CAT, Prado LL, Haddad F, Junqueira NTV (2012) Tecnologia de mudas enxertadas de maracujazeiro azedo para controle de doenças causadas por Fusarium spp. no Mato Grosso - a experiência da Coopernova. In: Congresso Brasıleıro De Frutıcultura, 22., Bento Gonçalves. Anais.Bento Gonçalves: SBF, 4p.

Silva CV, Oliveira LS, Loriato VAP, Silva LC, Campos JMS, Viccini LF, Oliveira EJ, Otoni WC (2011) Organogenesis from root explants of commercial populations of Passiflora edulis Sims and a wild passionfruit species, P.cincinnata Masters. Plant Cell, Tissue and Organ Culture, 107: 407-416.

Silva FM, Corrêa LS, Boliani AC, Santos PC (2005) Enxertia de mesa de Passiflora edulis Sims f. flavicarpa Deg. sobre Passiflora alata Curtis, em ambiente de nebulização intermitente. Revista Brasileira de Fruticultura, 27: 98-101.

Silva ML, Pinto DLP, Guerra MP, Floh EIS, Bruckner $\mathrm{CH}$, Otoni WC (2009) A. novel regeneration system for a wild passion fruit species (Passiflora cincinnata Mast.) based on somatic embryogenesis from mature zygotic embryos. Plant Cell, Tissue and Organ Culture, 99: 47-54.
Silva RM (2016) Enxertia de cultivares de maracujazeiro azedo sobre Passiflora foetida L.: desempenho agronômico das cultivares, caracterização morfoagronômica, variabilidade genética do porta enxerto e resistência à fusariose. 112f. Tese (Doutorado em Agronomia) - Programa de Pósgraduação em Fitotecnia, Universidade Federal Rural do Semi-Árido, Mossoró,

Silva RP, Peixoto JR, Junqueira NTV (2001) Influência de diversos substratos no desenvolvimento de mudas de maracujazeiro azedo (Passiflora edulis Sims $\mathrm{f}$. flavicarpa Deg.). Revista Brasileira de Fruticultura, 23(2): 377-381.

Souza PVD, Carniel E, Fochesato ML (2006) Efeito da composição do substratonoenraizamento de estacas de maracujazeiroazedo. Revista Brasileira de Fruticultura, 28(2): 276-279.

Torres GAM (2018) Seed dormancy and germination of two cultivated species of Passifloraceae. Bol.Cient.Mus. Hist.Nat.U.de Caldas, 22 (1): 15-27.

Tozzi HH, Takaki M (2011) Histochemical analysis of seed reserve mobilization in Passiflora edulis Sims fo. flavicarpa O. Deg. (yellow passion fruit) during germination. Brazilian Journal of Biology, 71(3): 701708.

Uzunoğlu F, Mavi K (2014) Tıbbi bir mucize; Çarkıfelek (Passiflora spp.) bitkisi. Uluslararası Mezopotomya Tarım Kongresi Bildiri Kitabı, s:620-624.

Uzunoğlu F, Mavi K (2016) Çarkıfelek (Passiflora caerulea L.) türünde indol butirik asit uygulamalarının çelik köklenmesi üzerine etkisi. Bahçe, 45 (Özel sayı): 943949.

Uzunoğlu F, Mavi K (2017) Farklı indol butirik asit uygulamalarının çarkıfelek (Passiflora caerulea L.) türünde fidan kalitesi üzerine etkisi. Bahçe, 46 (Özel sayı 1): 183-187.

Valle KD, Pereira LD, Barbosa MA, Chaves VBS, Souza PHM, Reis EF, Hurtado-Salazar A, Silva DFP (2018) Development and root morphology of passion fruit in different substrates. Revista Colombiana de Ciencias Horticolas, 12(2): 514-520.

Vaz CF, Peixoto JR, Junqueira NTV, Braga MF, Santos ECD, Fonseca KG, Junqueira KP (2009) Rooting of wild species of passion fruit using five doses of Indole butyric acid. Revista Brasileira de Fruticultura, 31(3):816-822.

Veiga-Barbosa L, Mira S, Gonzalez-Benito ME, Souza MM, Meletti LMM, Perez-Garcia F (2013) Seed germination, desiccation tolerance and cryopreservation of Passiflora species. Seed Science and Technology, 41: 89-97. 
Viana ML (2016) Enraizamento de estacas de cultivares demaracujazeiro ornamental. Monografia (Trabalho de Conclusão de Curso) - Faculdades Integradas, Planaltina, DF. p:26.

Vieira LM, Rocha DI, Taquetti MF, Silva LC, Campos JMS, Viccini LF, Otoni WC (2014) In vitro plant regeneration of Passiflora setacea D.C. (Passifloraceae): the influence of explant type, growth regulators, and incubation conditions. In Vitro Cellular and Developmental Biology - Plant, 50: 738-745.

Vieira MLC, Oliveira EJ, Matta FP, Pádua JG, Monteiro M (2005) Métodos biotecnológicos aplicados ao melhoramento genético do maracujá. In: Faleiro FG, Junqueıra NTV, Braga MF (Ed.). Maracujá: germoplasma e melhoramento genético. Planaltina, DF: Embrapa Cerrados, p.411-453.
Vivian R, Silva AA, Gimenes J, Fagan EB, Ruiz ST, Labonia $V$ (2008). Dormência em sementes de plantas daninhas comomecanismo de sobrevivência: breverevisão. Planta Daninha, 26: 695-706.

Wagner Junior A, Alexandre RS, Negreiros JRS, Parizzotto A, Bruckner CH (2005) Influence of seed scarification and imbibition time on passion fruit. Revista Ceres, 52(301): 369-378.

Zucarelli V, Ferreira G, Amaro ACE, Araujo FPD (2009) Photoperiod, temperature and plant growth regulators on germination of Passiflora cincinnata seeds. Revista Brasileira de Sementes, 31: 106-114. 